\title{
A Comprehensive Review on Design, Monitoring, and Failure in Fixed Offshore Platforms
}

\author{
Nima Amiri ${ }^{1}$, Mohammad Shaterabadi ${ }^{2}$ (D), Kazem Reza Kashyzadeh ${ }^{3, *(D)}$ and Mahmoud Chizari ${ }^{4, *(D)}$ \\ 1 Department of Mechanical Engineering, Sharif University of Technology, Tehran 11155-1639, Iran; \\ nimaamiri25@gmail.com \\ 2 Department of Electrical Engineering, Kermanshah University of Technology, Kermanshah 67156-85420, Iran; \\ MohammadShaterabadi@gmail.com \\ 3 Department of Transport, Academy of Engineering, Peoples' Friendship University of Russia \\ (RUDN University), 6 Miklukho-Maklaya Street, 117198 Moscow, Russia \\ 4 School of Physics, Engineering \& Computer Science, University of Hertfordshire, Hatfield AL10 9AB, UK \\ * Correspondence: reza-kashi-zade-ka@rudn.ru or kazem.kashyzadeh@gmail.com (K.R.K.); \\ m.chizari@herts.ac.uk (M.C.)
}

check for updates

Citation: Amiri, N.; Shaterabadi, M.; Reza Kashyzadeh, K.; Chizari, M. A Comprehensive Review on Design, Monitoring, and Failure in Fixed Offshore Platforms. J. Mar. Sci. Eng. 2021, 9, 1349. https://doi.org/ 10.3390/jmse9121349

Academic Editor: Puyang Zhang

Received: 3 November 2021

Accepted: 23 November 2021

Published: 30 November 2021

Publisher's Note: MDPI stays neutral with regard to jurisdictional claims in published maps and institutional affiliations.

Copyright: (c) 2021 by the authors. Licensee MDPI, Basel, Switzerland. This article is an open access article distributed under the terms and conditions of the Creative Commons Attribution (CC BY) license (https:// creativecommons.org/licenses/by/ $4.0 /)$.

\begin{abstract}
Offshore platforms have had diverse applications in the marine industry, for example, oil or gas platforms can provide facilities to store the oil and gas before transport those to refineries. Offshore wind turbines are another well-known use of the offshore platform for generating power. As platforms encounter various strong forces from water and wind currents, the materials used for these structures are mainly steel or concrete. These platforms are classified into different types, according to the depth of water and their applications. In addition, offshore platforms, as artificial reefs may be used for decades at different marine conditions. Consequently, their design and maintenance are very important, otherwise, they can cause irreparable damage to the environment. This paper presents the latest and most significant design and monitoring methods, such as the optimal probabilistic seismic demand model, multi-objective optimization, dynamic response assessment, robust fault-tolerant control, etc., under different environmental and geographical conditions. Moreover, the effective factors on the life and failure of these offshore structures are comprehensively introduced to enhance awareness of them, which can be very helpful to improve the design and construction of more reliable and durable structures.
\end{abstract}

Keywords: coastal structure; environmental marine issue; failure analysis; marine ecology; marine structure

\section{Introduction}

Offshore platforms are large structures, and have drilling rigs for the exploration, extraction, storage, and processing of crude oil and natural gas from the seabed. These are commonly used in the oil industry, but they are also used in radio broadcasting, for navigation lights, radar monitoring, space operations, and oceanographic research. Although most offshore platforms are equipped with devices to better adapt to their surroundings, the most common ones are used for submarine activities, as well as those that can also be used in lakes and in coastal waters. The first step in designing an offshore platform is to get an accurate understanding of the structure, based on its functional needs, environmental constraints, and method of construction. Therefore, considering the environmental and geographical aspects, and also the method of construction, in designing offshore platforms, several important factors, such as environmental loads, construction stages, economic aspects, method of construction, date, and place of installation should be considered. Depending on the circumstances, offshore platforms may be fixed or floating on water. Fixed platforms are generally built for production and floating platforms are used exclusively for exploration and drilling operations. Over the last five decades, different 
types of offshore platforms have been designed and used, such as jack-up rigs, semisubmersible platforms, drillships, compliant towers, fixed platforms, normally unmanned installations, spar platforms, and tension-leg platforms. The diversity of these structures is due to various factors, such as scientific and technical processes, economic factors, the need to use deeper natural reservoirs, and environmental constraints. Offshore platforms are constantly exposed to lateral forces from water and wind currents [1]. Therefore, the effects of these forces and the water pressure of different distances on marine structures, especially platforms, must be considered [2]. During service life, offshore platforms may be exposed to various loads that are larger than the conditions considered in the design phase. As a result, it is very important to study their roles and effects on evaluating the longevity of existing offshore platforms to continue operations and in designing new reinforced platforms. The difference between fixed and floating platforms lies in how they deal with environmental side effects (i.e., waves and wind effects). As their name implies, fixed platforms are older structures; this means that, although they are in seawater, their deformation is minimal in the face of side effects. Unlike fixed platforms, floating platforms are designed to be mobile against lateral forces. As a result, this reduces the effects of these forces [3].

In recent years, one of the most important applications of offshore structures has been to produce electricity using wind turbines, which provides $3 \%$ of the European Union's (EU) power demand. Currently, offshore wind farms in Europe (12 countries) generate about $26.4 \mathrm{GW}$ of energy, which is expected to reach about $111 \mathrm{GW}$ over the next decade. This significant outlook shows the great importance of this sector in producing clean and safe energy for countries [4]. In addition, offshore wind turbines have far fewer problems than onshore wind turbines in terms of adverse effects on the environment, and the most serious environmental problem is related to migratory birds, which the location of offshore wind farms should consider based on migration routes. It is necessary to pay attention to the dynamic behavior of offshore turbines under wave and wind forces, and their strength under these loads should be taken into account as an important design criterion for all offshore wind turbines. Due to the depth of the sea, different types of these offshore turbines are used, in which the main difference is related to their platforms, such as monopile, tripod/jacket, floating structures and the tension leg platform (TLP), semi-submersible (semi-sub), and spar buoy (Spar) [5].

In addition to the forces caused by waves and wind, corrosion is another very important and influential factor on the service life of these marine structures. Corrosion occurs when existing electrolytes experience electrochemical reactions with their environment. Common factors that affect the corrosion rate of offshore platforms in an area are relative humidity, temperature, wind speed, and salinity [6]. With the passage of time and due to progress in the industry, more durable materials, such as reinforced concrete and steel, have been used to build offshore structures to overcome the corrosion problems. However, offshore platforms are often exposed to hazards and accidents that cause them to erode and collapse. Accordingly, investigating and identifying the factors affecting the failure and collapse of offshore platforms is a serious matter. Among the hazards that threaten offshore platforms, three groups are more significant than others: low platform safety, risks due to unexpected accidents, and risks due to errors during the design and construction of platforms. Unexpected forces are another category of factors that cause natural and abnormal damage; for example, forces due to a collision with a ship or ice chunks with the platform. Moreover, the forces caused by explosions, storms, and earthquakes can be more than platform resistance expects and cause it to fail $[7,8]$. Using various methods such as weight reduction, increasing hardness and strength, changing the use, and eliminating irregularities, it is possible to increase the strength of offshore platforms. In addition to the above methods, in special circumstances, to strengthen platforms, their parts can be replaced or strengthened by adding additional parts. However, this method causes asymmetry in a platform and is very difficult and costly. Energy dissipation systems are another technique used to strengthen offshore platforms. This is the most convenient and 
cost-effective method compared to the previous methods. In addition, using this method does not cause structural problems, such as asymmetry in the platform. The purpose of reinforcement is to enhance the service life of the offshore platforms by increasing resistance to various forces. Furthermore, with structural improvements, the problems and shortcomings that existed during the initial operation of the platform can be eliminated. Finally, the power of the platform can be increased against the forces caused by the addition of equipment and personnel on the deck.

As mentioned, the importance of using these marine structures is very high, and therefore it is very crucial to pay attention to the conditions that affect their quality and service life. The present paper reviews the latest practical methods and approaches affecting the design, construction, control, and reliability, as well as the most important factors influencing the failure and fatigue life of offshore platforms.

\section{Design and Monitoring}

One of the important factors in the design of offshore platforms is robustness, which is, in fact, a prerequisite to prevent design failure; this goal is achieved when structural responses are proportional to the applied forces. In this regard, various forms of forces, such as overload, accidental loads, failure of members, etc., can be applied to the structure, which are divided into two categories: predictable and unpredictable scenarios [9]. Steel is one of the most widely used materials in the construction of offshore platforms, and proper design and maintenance are important proceedings in the field of increasing robustness. One of the methods used to evaluate the quality of steel structures is the use of robustness assessment methods that can be assessed under various conditions, such as catastrophic events [10]. The fuzzy method is a novel and applied method in research sciences. This method has a high ability to work with vague information, that is partially true, uncertain, without sharp boundaries, and is imprecise [11,12]. In addition, this method allows the involvement of ambiguous human evaluation, conflict resolution, and more detailed examination of all situations and options, and among its applications, can be used for pattern recognition, optimization, control, decision making, and identification [13]. Studies have shown that fuzzy methods in the field of robustness assessment considering the effects of corrosion are more conservative compared to traditional methods, and results can be expanded to more complex conditions [14]. Structural reinforcement methods vary depending on conditions such as different defects and maintenance. One of the effective methods in strengthening offshore platforms is X-type grouting clamps, as shown in Figure 1, which increases the strength and bearing capacity of a pipe joint [15]. In another research, the use of the reinforced grouted clamp prototype pipeline has been proposed to reduce the pipe center stress under axial pressure, and increase the strength, reliability, and safety of offshore platforms [16].
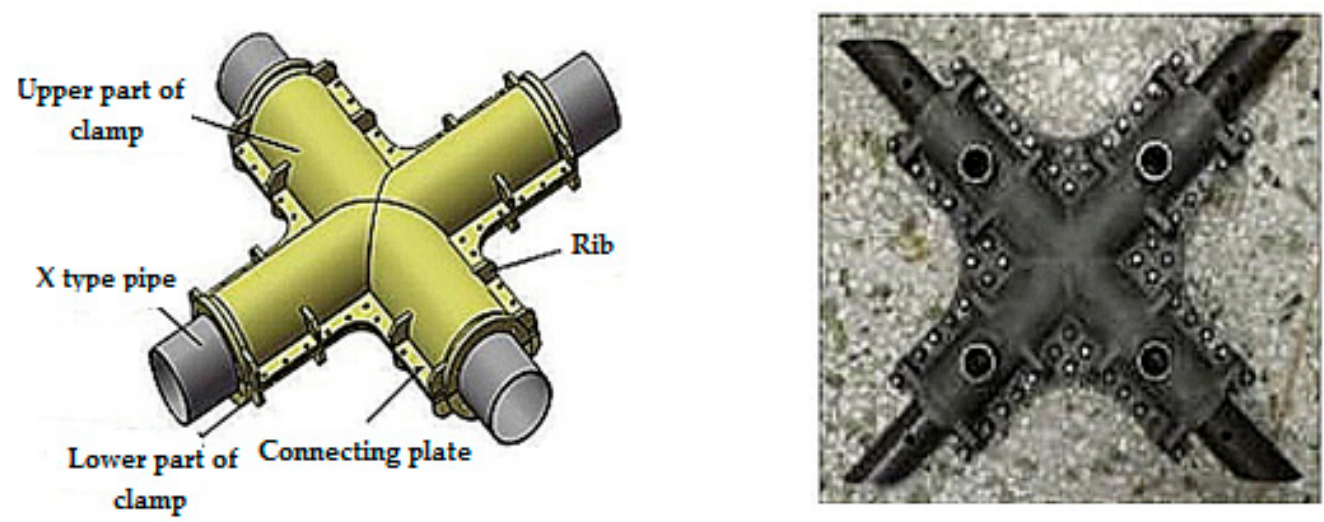

Figure 1. X-type grouting clamps [15]. 
Using a buoyant mass damper (HBMD), which engages damper buoyancy, inertial forces, and hydrodynamic damping effects, is another way to strengthen platforms against flow forces, as illustrated in Figure 2. The results with a four-legged platform showed that the correct location and attachment of HBMDs reduce the response of the platform to wave forces [17].

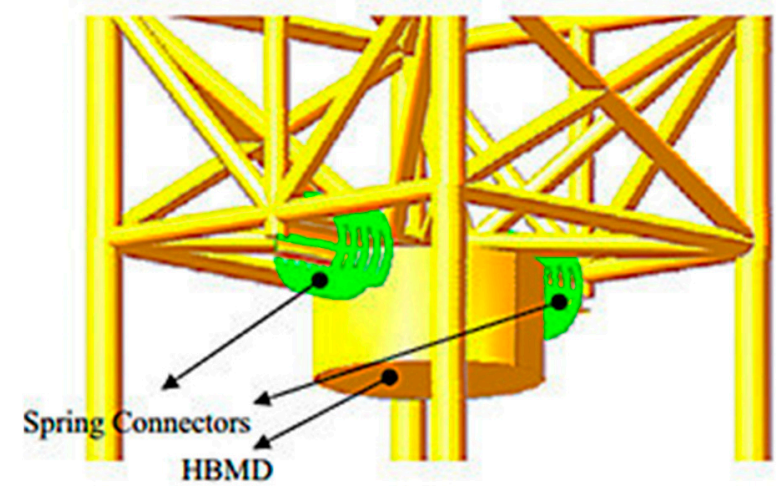

Figure 2. Schematic of the hydrodynamic buoyant mass damper (HBMD) [17].

In general, active vibration control using different types of dampers is a common method to reduce damage and fatigue due to shakes; however, there should be sufficient attention on the selection of dampers, because the characteristics of dampers and their performance depend on various factors, including structural and environmental issues, such as normal-condition or extreme-condition loads. In 2014, Jafarabad et al. attempted to reduce the destructive vibrations on offshore platforms using a combination of friction damper devices (FDDs) and a tuned mass damper (TMD), as demonstrated in Figure 3a,b, respectively. In their study, they also incorporated the effects of earthquakes. Additionally, they proposed a hybrid damping system (HDS), was a damper with a higher performance and better vibration reduction in comparison with other types of dampers (Figure 3c) [18]. The results of numerical studies showed that the use of feedforward and feed-back optimal tracking control (FFOTC and FBOTC, respectively) is appropriate to reduce the waveinduced vibration and the required control force. This proposal was obtained by solving Riccati and Sylvester equations $[19,20]$. In addition, the usage of incremental dynamic analysis (IDA) has been proposed as a powerful tool in assessing the capacity of offshore platforms in the face of seismic loads [21].

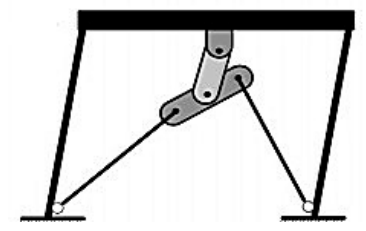

(a)

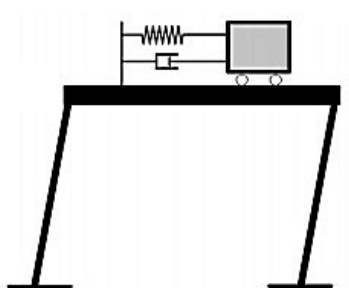

(b)

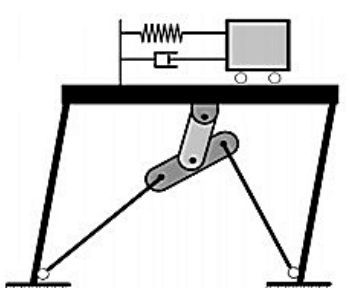

(c)

Figure 3. Three types of damping systems in the offshore jacket platforms [18]. (a) FDD, (b) TMD, (c) HDS.

In the design process, the possible occurrence of some events must be considered according to geographical situations. For example, in a review of the requalification of platforms in the Bay of Campeche located in the southern area of the Gulf of Mexico, it was found that the risk assessment and management (RAM) method considering hurricane and earthquake criteria was useful and practical for the design and requalification of offshore platforms [22]. The Cook Inlet, Barent Sea, Caspian Sea, the Bohai Bay of China, etc., are common places where sea surface freezing is possible in shallow parts, therefore, offshore 
platform should be designed to consider the effects of ice or freezing loads (Figure 4). In designing oil platforms in these areas, two basic factors need to be considered: ice loads and the failure modes of slender ice-resistant structures. Examining the impacts of dynamic ice loads and ice-induced vibrations on steel offshore platforms found that ice-induced structural vibrations cause severe shaking of the deck and reduced the fatigue life of platforms due to the cyclical stresses on the tubular nodes [23].
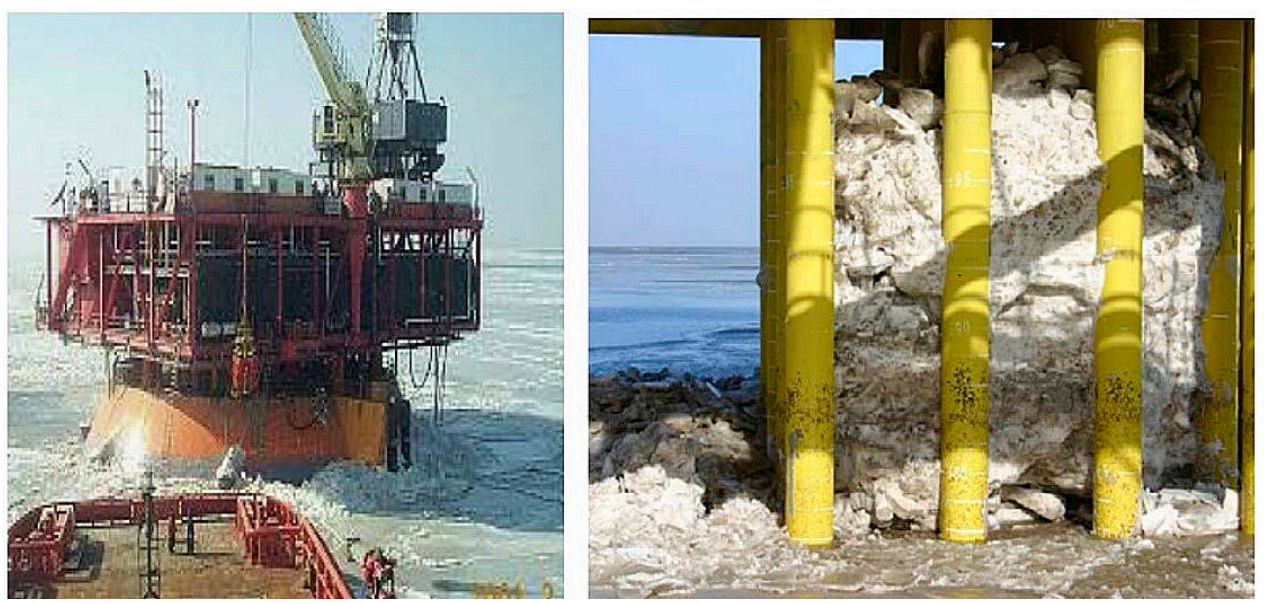

Figure 4. Offshore platforms with icy mode conditions [23].

Wang et al. investigated an ice-induced vibration model called an isolation cone system, including cones, springs, and dampers, which was mounted on the pile of an offshore platform, as shown in Figure 5. However, the proposed model requires experiments to determine how much it can repel the effects of extreme ice forces [24]. Utilizing rubber bearings and magnetorheological dampers are other methods to decrease the influence of ice- and earthquake-induced vibrations $[25,26]$.

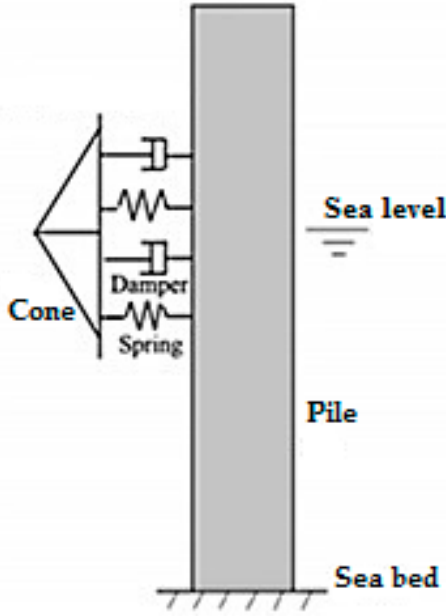

(a)

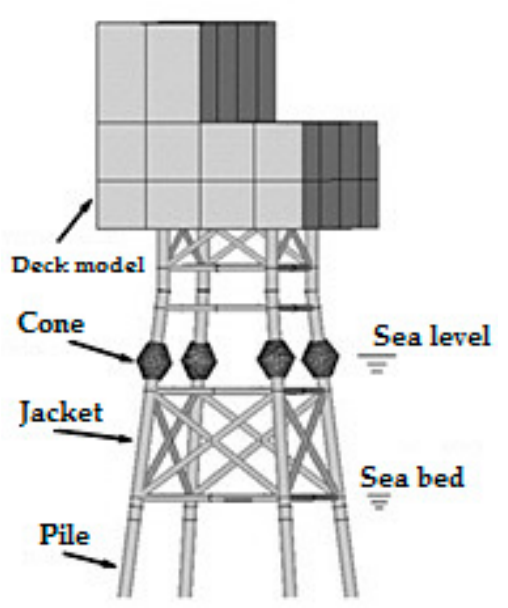

(b)

Figure 5. The general scheme of ice-induced vibration reduction by isolation cone system [24]. (a) Diagram of isolation cone system, (b) Model of the isolation cone system.

The effect of the soil-structure interactions (pile-soil-pile) on the system response and bending moment is another important factor that should be considered in calculations and evaluations. In other words, the behavior of soil changes in terms of environmental conditions and even moves due to wind and water, and, therefore, this issue has a significant influence on choosing site and type of platforms [27]. For this reason, it is strongly 
recommended not to ignore the effects of soil in simulations and calculations in order to obtain results that are more reliable and closer to reality. Figure $6 a, b$ illustrate the effect of soil subsidence or movement that creates an additional force called the wave-in-deck load. This extra force disturbs the balance of platforms and can cause significant damage and eventually collapse of the platform. Figure $6 \mathrm{c}$ shows the impact of the presence or absence of the wave-in-deck load on the failure probability of two different platforms, which increases the failure probability up to $100 \%$ in the presence of this excess load [28].

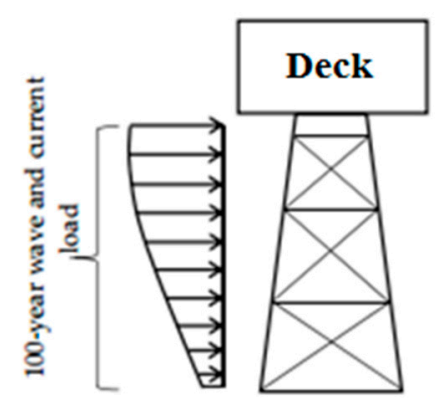

(a)

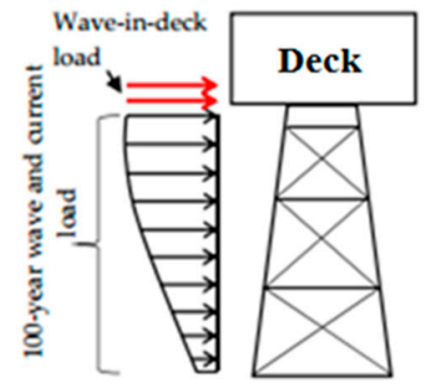

(b)

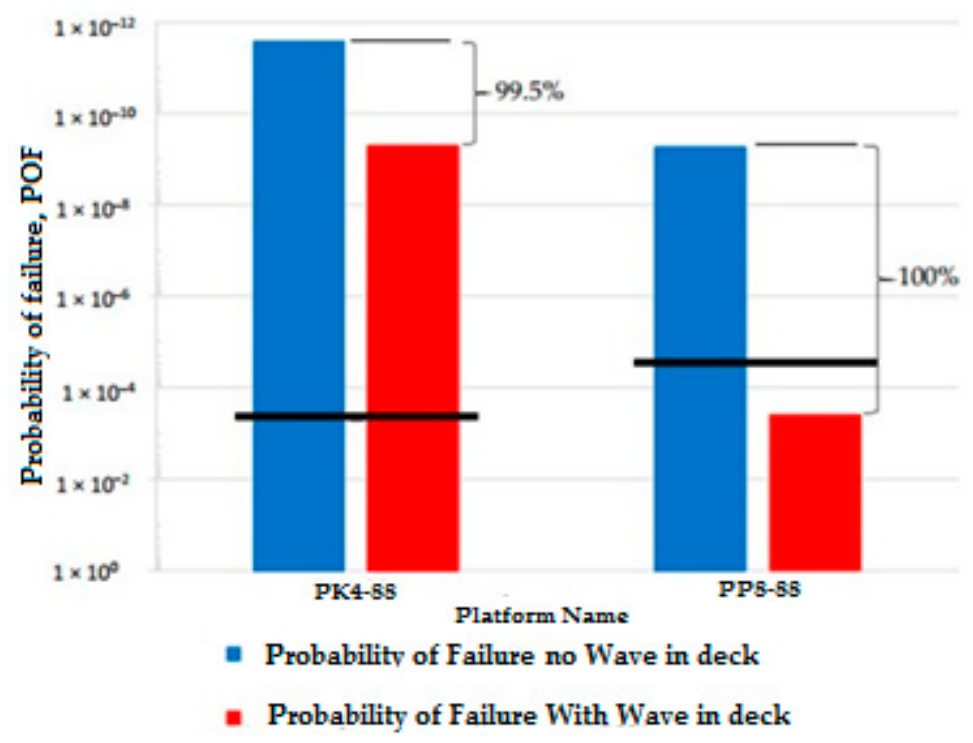

(c)

Figure 6. Comparison of the soil effect on the failure probability of two different offshore platforms [28]. (a) Conventional method, (b) Inclusion of wave-in-deck load, (c) Failure probability of different platforms with and without wave-in-deck load.

Today, in all sectors, including in the automotive industry, aerospace, construction, etc., reducing costs and increasing reliability are two primary and essential goals. Different optimization methods are divided into single and multi-objective, and each of them depends on the correlation and the number of parameters, as well as solving times. As presented in Table 1, the methods and constraints are changed according to the goal that a researcher pursues, and choosing the appropriate methods and constraints are significant challenges, which should be considered carefully. Therefore, the initial steps of the design and construction of offshore platforms are finding the most important and effective parameters based on local conditions and their correlation on each other by correlation coefficient. 
Table 1. The summary of various novel optimization methods used for offshore platforms.

\begin{tabular}{cccc}
\hline Author & Year & Method & Results \\
\hline $\begin{array}{c}\text { Hosseini and } \\
\text { Zolghadr [29] }\end{array}$ & 2017 & $\begin{array}{c}\text { Metaheuristic algorithm, } \\
\text { namely cyclical } \\
\text { parthenogenesis algorithm } \\
\text { (CPA) }\end{array}$ & $\begin{array}{c}\text { Minimum weight } \\
\text { jacket-type }\end{array}$ \\
\hline Zhang et al. [30] & 2018 & $\begin{array}{c}\text { Tension leg platform (TLP) } \\
\text { optimization program } \\
\text { (multi-objective optimization) }\end{array}$ & $\begin{array}{c}\text { Maximum dynamic tension } \\
\text { and the total weight of the } \\
\text { platform }\end{array}$ \\
\hline El-Makarem et al. & 2019 & $\begin{array}{c}\text { Automated optimization } \\
\text { method (automated iterative } \\
\text { method of gradually topology } \\
\text { optimization) }\end{array}$ & $\begin{array}{c}\text { Safe structure during } \\
\text { earthquake event with a } \\
\text { minimum total weight }\end{array}$ \\
\hline Tian et al. [32] & 2019 & $\begin{array}{c}\text { Topology optimization method } \\
\text { Deng et al. [33] }\end{array}$ & $\begin{array}{c}\text { Maximize the structural } \\
\text { stiffness }\end{array}$ \\
\hline Babaei et al. [34] & 2020 & Topology optimization method & $\begin{array}{c}\text { The maximum stiffness } \\
\text { considering wind, wave, } \\
\text { and ice loads }\end{array}$ \\
\hline 2021 & Probabilistic seismic demand \\
analysis (PSDA) & $\begin{array}{c}\text { Intensity measures (Ims) } \\
\text { and engineering demand } \\
\text { parameters (EDPs) }\end{array}$ \\
\hline
\end{tabular}

Assessing and monitoring the health of marine structures are crucial due to financial and human issues, therefore various methods have been presented and developed to evaluate these structures. Seismic fragility curves are one of these methods to assess the integrity of marine structures. In improving the quality of seismic fragility curves, the response rate of each level of the structure during an earthquake can be calculated considering aleatory and epistemic uncertainty based on nonlinear dynamic analysis [35]. Nevertheless, prioritization, strengthening, modification, and repair plans are vital issues in the maintenance of both new and old offshore platforms. In 2015, in an interesting study by Samarakoon et al., a multi-criteria analysis (MCA) that included an analytical hierarchy process (AHP) for structural integrity control (SIC) was examined (Figure 7) [36,37]. The use of structural monitoring systems (SMS) is a method that has been proposed to monitor and enhance the life of offshore platforms in the North Danish Sea. To this end, various types of equipment, such as accelerometers, GPS, strain gauges, and wave radars were utilized [38].

A comparison has also been made between a tuned mass damper (TMD) and semiactive tuned mass damper (SATMD), in which the activity is controlled by a fuzzy logic controller (FLC) under various natural factors, such as water waves, sea currents, wind, and earthquake. From Figure 8, SATMD has a greater ability to reduce lateral displacement, velocity, acceleration, base shear, and overturning moment [39].

Over time, different control schemes, such as nonlinear controllers, delayed dynamic output feedback controller (DDOFC), etc., have been reviewed. H-infinity $\left(H_{\infty}\right)$ methods are used in control theory to combine controllers with the aim of achieving stabilization with proper performance. Recently, this controller has been widely used in the field of offshore platforms subjected to different conditions. Table 2 presents some examples of effective $H_{\infty}$ s. However, there is no appropriate comparison between these controllers, in other words, they have only been compared with conventional controllers. Therefore, it seems that a comprehensive study on the $H_{\infty}$ method with obvious patterns is required. 


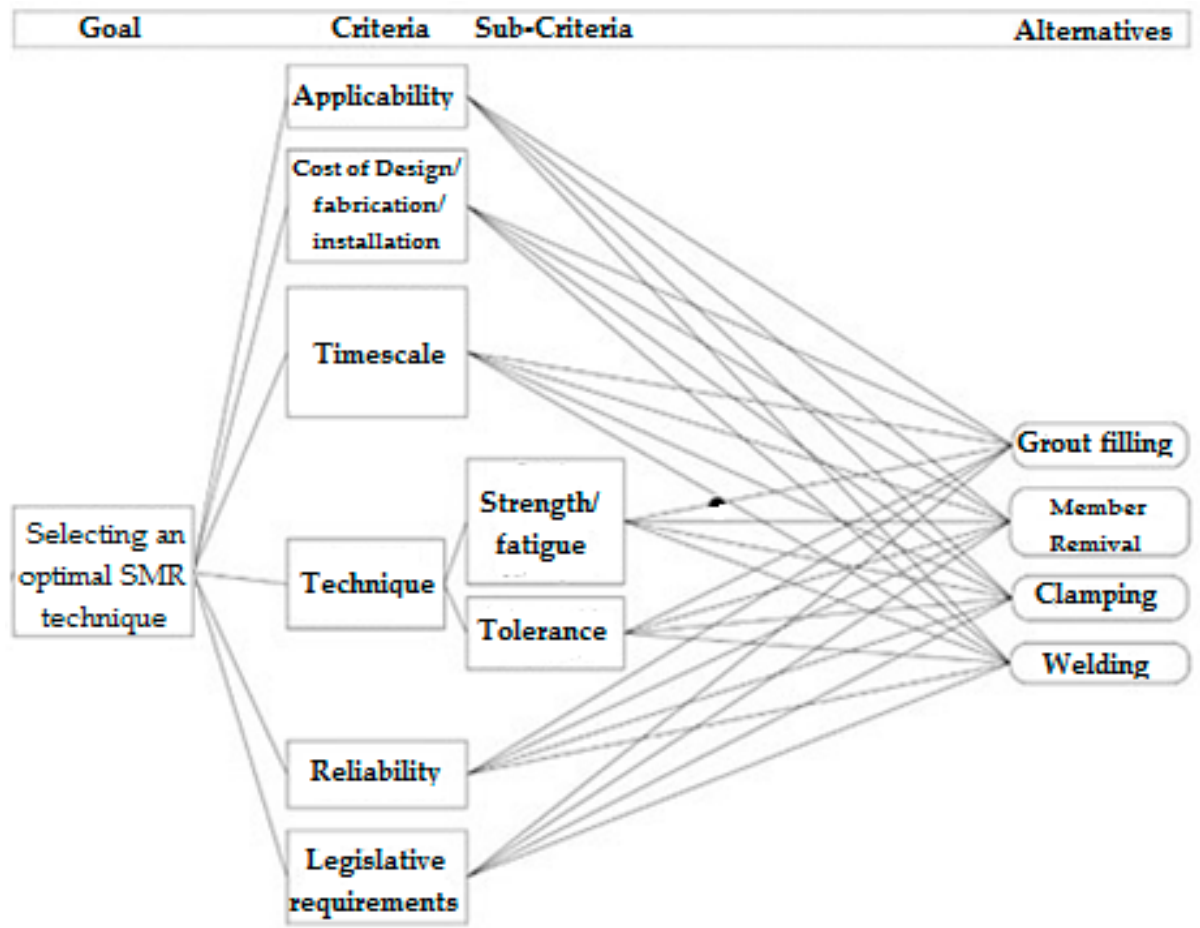

Figure 7. The structure of the analytical hierarchy process for selecting SMR techniques [37].

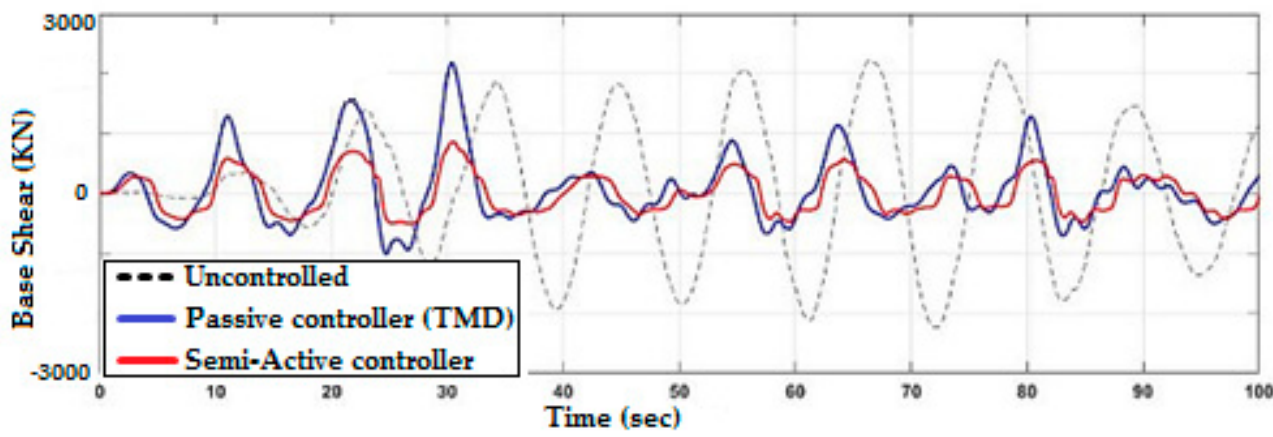

(a)

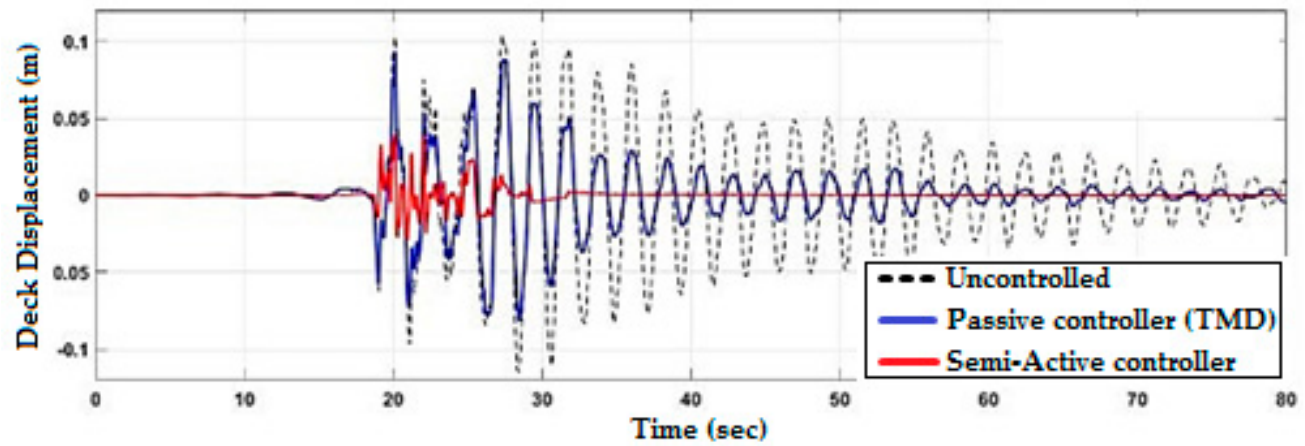

(b)

Figure 8. Comparison of the tuned mass damper with semi-active tuned mass damper [39]. (a) Base shear reduction via environmental loading, (b) The main deck lateral deflection under earthquake load. 
Table 2. Various $H_{\infty}$ controller.

\begin{tabular}{|c|c|c|c|}
\hline Author & Year & Method & Results \\
\hline $\begin{array}{l}\text { Zhang et al. } \\
\text { [40-42] }\end{array}$ & 2005-2013 & $\begin{array}{l}\text { Delayed non-fragile } \\
\qquad H_{\infty}\end{array}$ & $\begin{array}{l}\text { Vibration reduction } \\
\text { The smaller control forces } \\
\text { Better control performance }\end{array}$ \\
\hline $\begin{array}{l}\text { Zhang and Han } \\
{[43]}\end{array}$ & 2013 & $\begin{array}{l}\text { Robust sliding mode } \\
\qquad H_{\infty}\end{array}$ & $\begin{array}{l}\text { Effects of time-varying delays } \\
\text { on robust sliding mode } H_{\infty} \\
\text { control }\end{array}$ \\
\hline $\begin{array}{l}\text { Yang } \\
\text { [44] }\end{array}$ & 2014 & $\begin{array}{l}\text { Robust mixed } \\
H_{2} / H_{\infty} \\
\text { control }\end{array}$ & $\begin{array}{c}\text { Minimization of the upper } \\
\text { bound of the } H_{2} \text { performance } \\
\text { measure } \\
\text { Improvement of dynamic } \\
\text { performances }\end{array}$ \\
\hline $\begin{array}{l}\text { Sakthivel et al. } \\
\text { [45] }\end{array}$ & 2015 & $\begin{array}{l}\text { Robust fault-tolerant } \\
\text { sampled-data } H_{\infty} \\
\text { (control forces) }\end{array}$ & $\begin{array}{c}\text { The safety and comfort level of } \\
\text { the offshore structure } \\
\text { Better effectiveness }\end{array}$ \\
\hline $\begin{array}{l}\text { Zhang et al. } \\
\text { [46] }\end{array}$ & 2016 & $\begin{array}{l}\text { Event-triggered } H_{\infty} \\
\text { with the } \\
\text { network-based } \\
\text { modeling }\end{array}$ & $\begin{array}{l}\text { Guaranteeing the stability } \\
\text { Saving the communication } \\
\text { resources } \\
\text { Less control cost than simple } \\
\text { controllers }\left(H_{\infty}\right)\end{array}$ \\
\hline
\end{tabular}

In another study, it was reported that by solving the algebraic Riccati equation and Sylvester equations, feedforward and feedback optimal fault-tolerant controller based on dynamic fault observer design can be produced, which improves reliability and reduces the control force, vibration amplitudes of the displacement, and velocity [47].

One of the most common events that cause damage and shortens the life of naval platforms is collisions with ships and other floating objects, because ships are constantly moving, docking to carry oil/gas and staff. In this regard, using probabilistic collision-risk analysis can predict the probability of collision and the amount of damage. According to Figure 9, to perform a probabilistic collision-risk analysis, the traffic information of ships should be collected in a first step from a valid database, such as the Automatic Identification System (AIS) database. Then, the frequencies and energies of the possible collisions are calculated. To this end, all types of ships that pose a risk to a platform are considered, but the degree of risk depends on various factors, including marine operations, traffic density, and the location of the facility [48].

In a computational study conducted in 2020, a platform collision with a vessel was modeled using the nonlinear explicit finite element code. In addition, the effects of various factors, such as velocities and locations, on the severity of damage to offshore platforms were analyzed. Figure 10a shows findings on the tubular member deformation, which undergoes local and then global deformation. However, the transition from local to global or vice versa depends on two parameters: thickness and strength of the colliding structures. The energy absorbed by the collision of the vessel and platform is shown in Figure 10b. It can be inferred that the fracture strain increases exponentially according to increasing thickness [49,50]. 


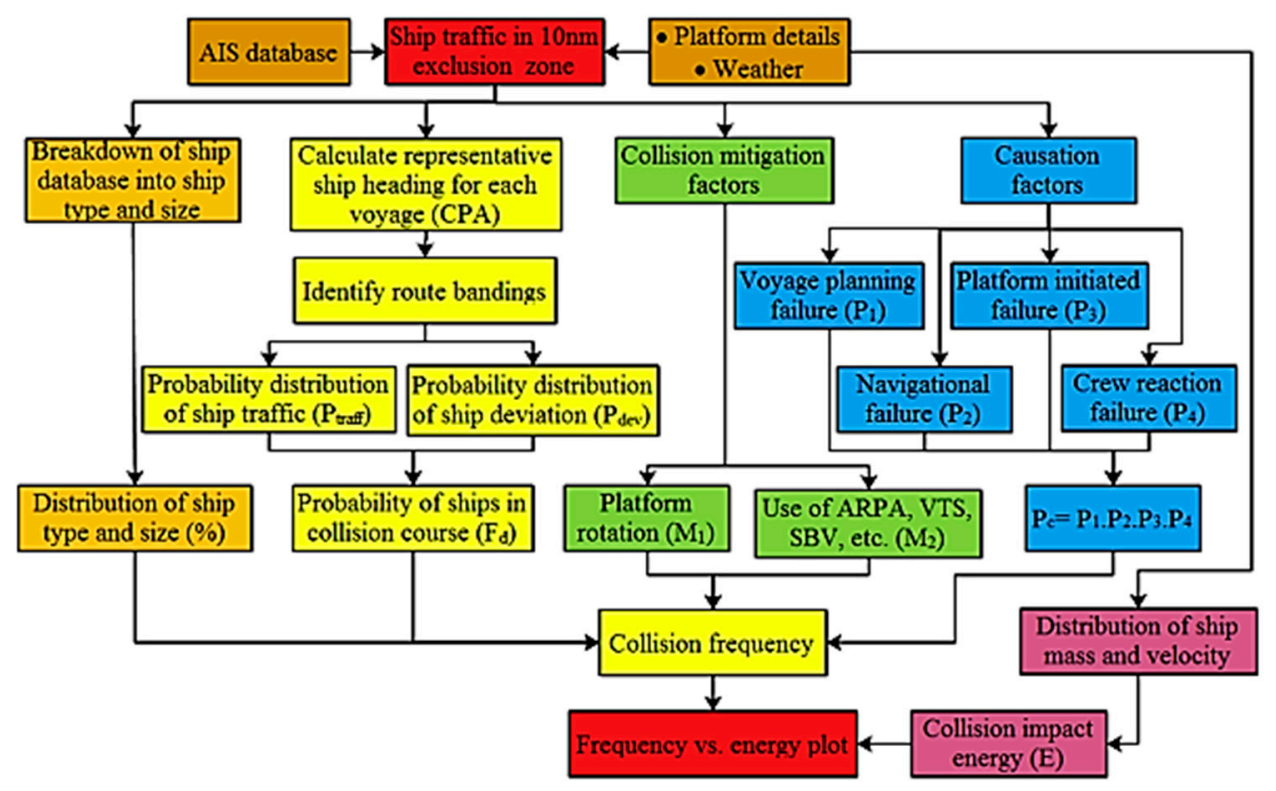

Figure 9. Risk analysis of ship-offshore platform collision [48].
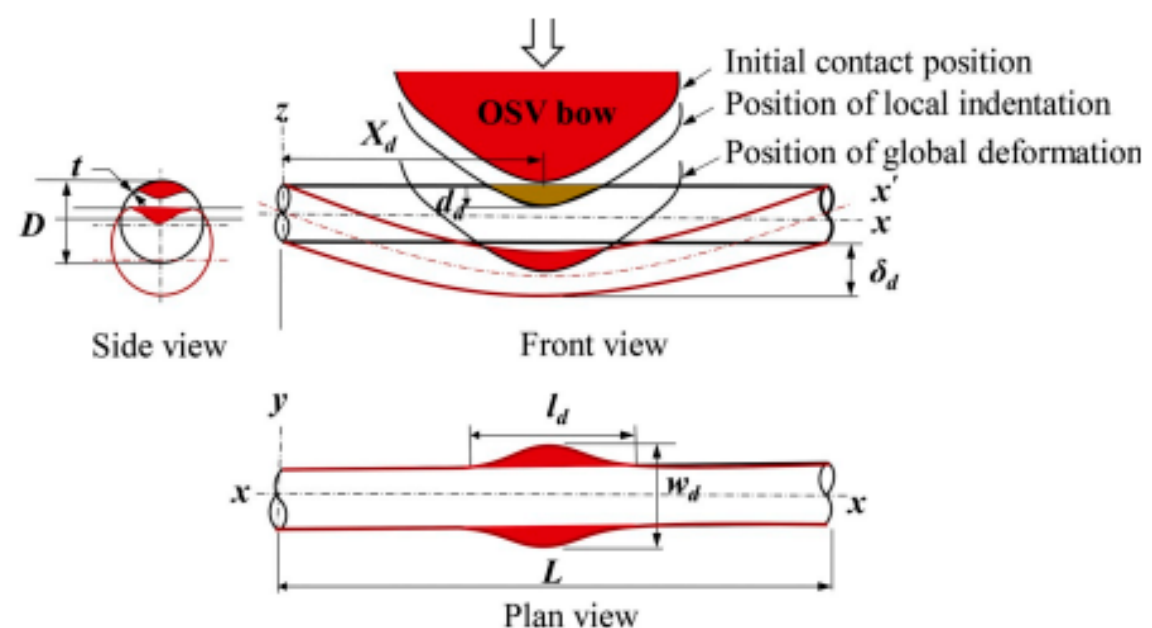

(a)

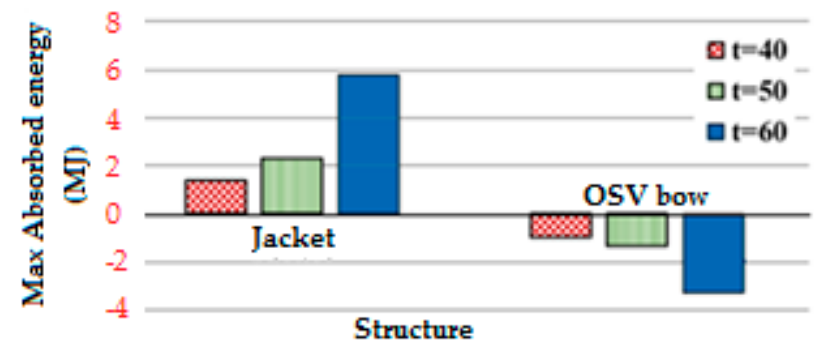

(b)

Figure 10. The collision's effects of the OSV's bow and jacket structure on absorbed energy and a deformed tubular member [49]. (a) A schematic diagram showing local denting and overall bending of a tubular, (b) Difference in maximum absorbed energy.

As a result, strengthening the members of the offshore platforms is very important. Hence, the tubular members need more research attention, as the members maintain the overall structure of platform, and their proper construction affect the service life of the platform. The corrosion, which may significantly affect the service life of platforms, has led recent studies to deeply investigate and try to reduce its impacts. Ahn et al. investigated 
the effect of this factor using artificial corrosion on tubular members. In that study, six scenarios were performed under different conditions, including pitting damage using a hand drill, damage by a mechanical process, corrosion area, depth and height, and different sectional properties. Figure 11 shows the effects of different corrosions on the behavior of tubular members under compressive loading, in which the R-T0 specimen was without corrosion, the R-PT3 specimen was subjected to the random pitting, and with the D-HPT3 and D-HT3 specimens only half were corroded with different artificial corrosion damage, and finally, the entire circumference of the D-FPT3 and D-FT3 specimens were corroded with various types of artificial corrosion damage. The results show that the amount of corrosion damage depends on the level of corrosion and the compressive failure mode. Moreover, the residual compressive stresses of corroded tubular members can be calculated by utilizing this method [51].

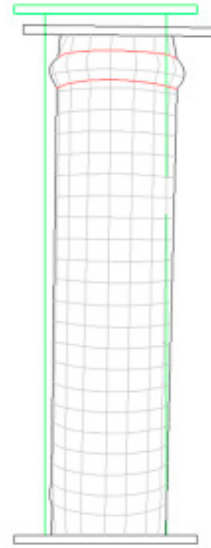

R-T0

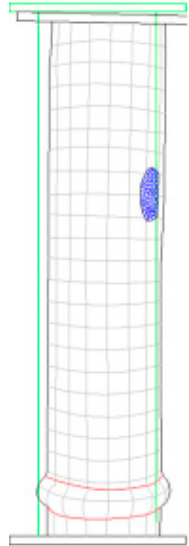

R-PT3

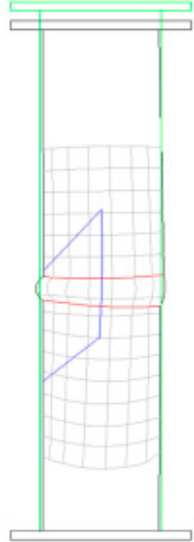

D-HPT3

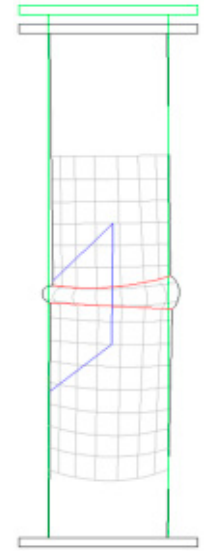

D-HT3

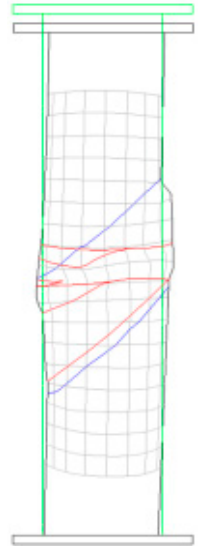

D-FPT3

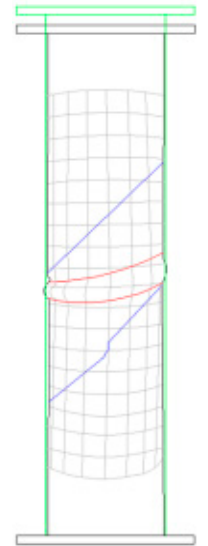

D-FT3

Figure 11. The specimens before and after the compressive loading tests [51]

In general, significant damage to offshore platforms starts with small accidents and defects; for example, cracks are one of the most common factors that may cause damage to a platform due to cyclic loads at different intervals (microcracks become macrocrack and spread with higher speeds). A vibration test (VT) is a type of NDT test in which, the condition of a part is determined by examining the symptoms and vibration parameters. In this method, the existence of defect is realized by analyzing the data recorded through displacement, speed, and acceleration sensors. VT accelerometers use a piezoelectric crystal. This crystal converts sound waves into electrical impulses or pulses. This part connects to a mass, which is the cover of the accelerometer, and vibrates due to the movements of the part. By vibrating the mass and the crystal, a low voltage current is generated and sent to the receiver through a preamplifier. In 2017, different algorithms and technologies were introduced for noise monitoring. A block diagram of this system is shown in Figure 12, which was tested using various defects, such as microcracks, pinholes, and micro deformation. It should be noted that this method only allows the monitoring of defects that lead to emergency states [52].

The application of new generation dampers based on multifunctional materials has been extended. Shape memory alloy (SMA) [53] and magnetorheological fluid (MRF) are two well-known models of new generation dampers that increase the adjustability and adaptability of a system [54]. Four models of these dampers, viscous-based, MRFbased, SMA-based, and SMA-MRF-based, are shown in Figure 13. Due to this fact that the SMA-MRF-based model is a combination of the MRF and SMA models, it has better strain recovery and controllability features and cause a greater reduction in the drift ratio for both stories of a two-story frame subjected to earthquakes [55]. 


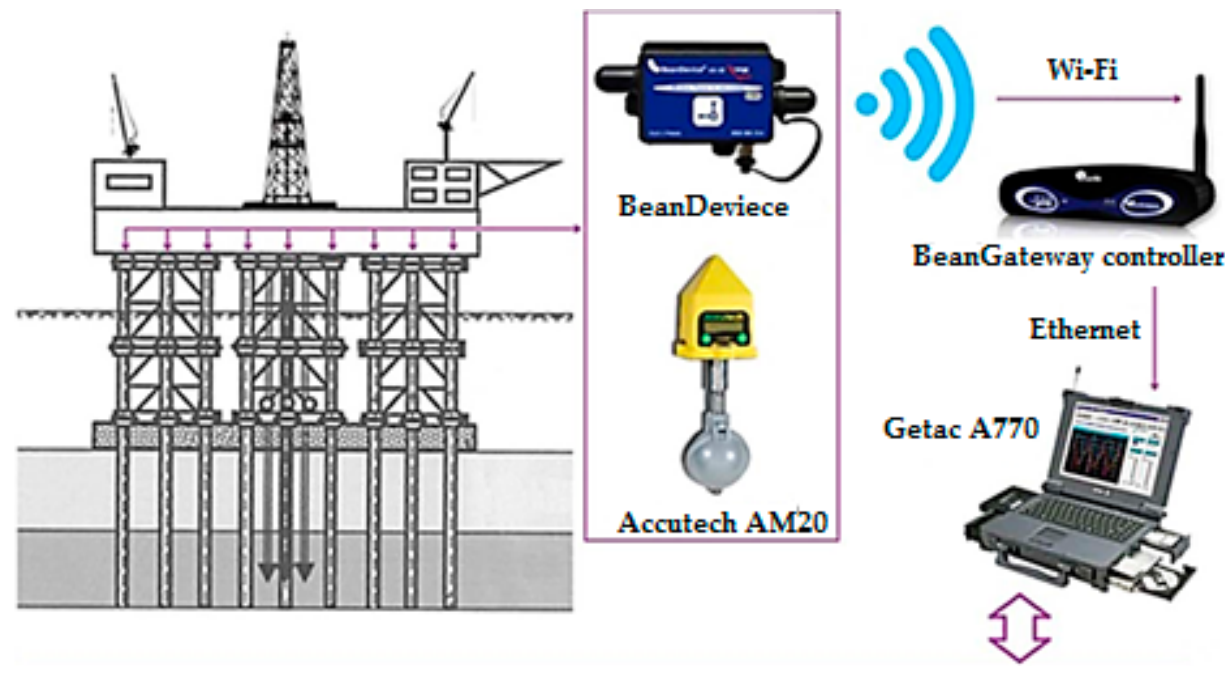

\section{System of robust noise monitoring}

Determination block of

correlation functions

and noise characteristics

of acoustic and

vibration signals
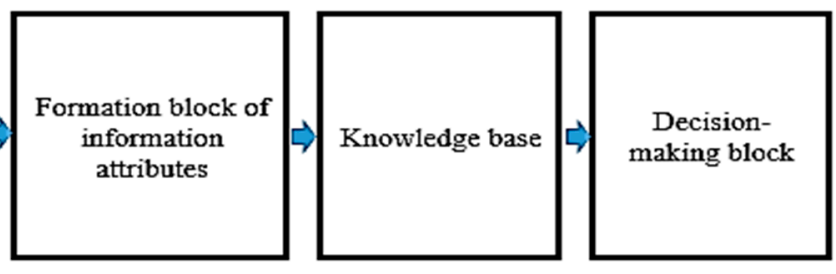

Figure 12. Block diagram of the noise monitoring system [52].

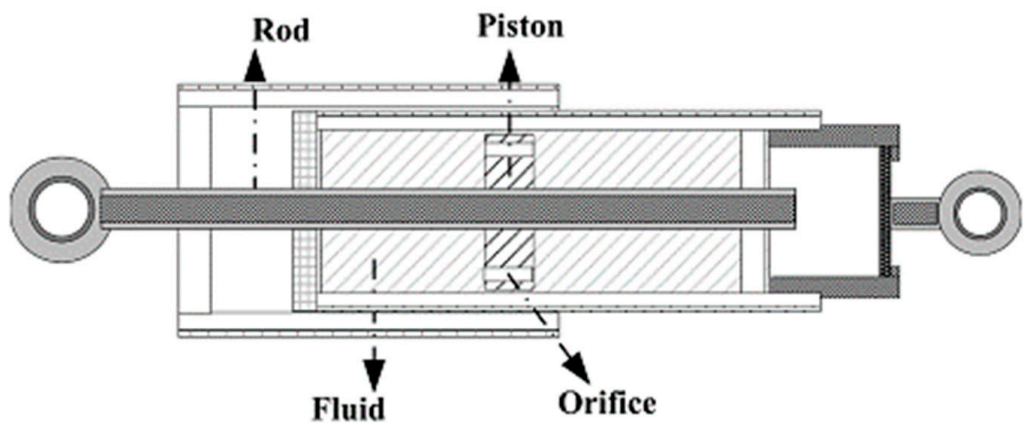

(a)

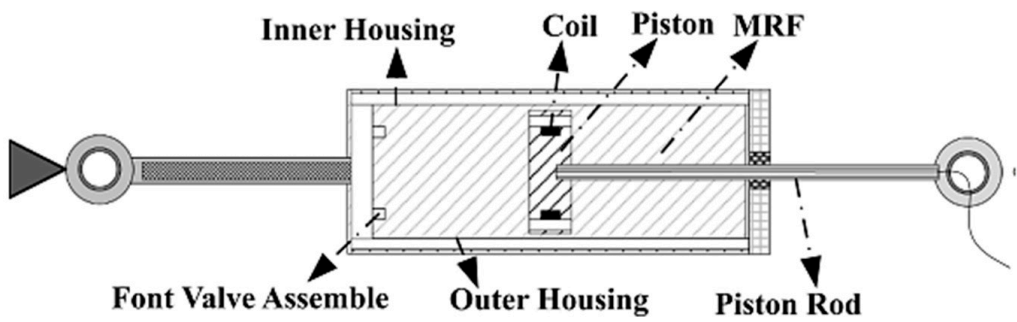

(b)

Figure 13. Cont. 


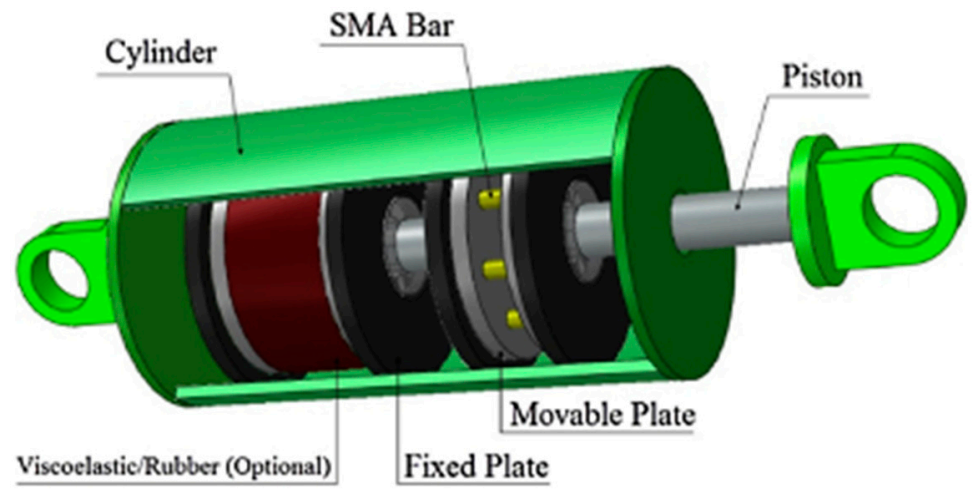

(c)
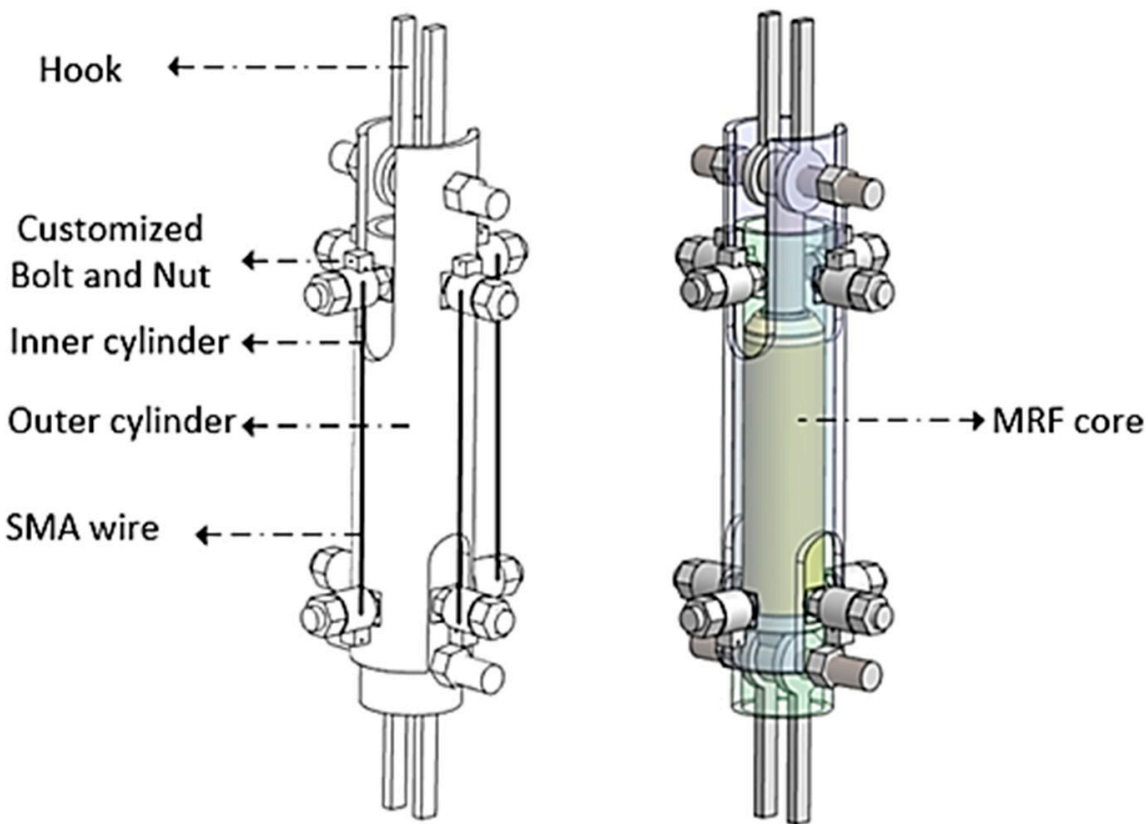

(d)

Figure 13. New generation dampers used for marine structures. (a) Viscous-based structural control system [55], (b) Magnetorheological fluid (MRF) [55], (c) The SMA damper [56], (d) SMA-MRF-based structural control system [55].

\section{Reliability and Failure Probability}

Reliability is a property of a system or element by which the probability of completing a mission or task, under specified conditions, for a predefined time period, can be assessed. In general, the reliability of a system is defined in terms of the failure probability. Thus, first, it is necessary to know all components of the system and then their types of failures can be predicted. After assessing the failure rate of a system, it will be possible to calculate the probability of the system operating within its constraints. Moreover, identifying the reliability index and the failure probability of the system are two key factors in assessing the integrity and reliability of offshore platforms [57]. One technique for easily calculating offshore platform reliability is to convert the entire system to sub-scenarios. In other words, each member of the platform should be considered as a scenario and, with its failure, the 
load will be spread to other members, and the probability of failures of each member will change. Equation (1) calculates the failure probability of the entire system [58].

$$
p_{f}(\text { sys })=\sum_{k=1}^{k} P_{s c e}(k)
$$

where $p_{f}(s y s)$ represents the failure probability of the entire system, $k$ is the whole number of scenarios, and $P_{s c e}$ is the occurrence probability that is related to each scenario.

In reliability calculations, all factors which affect the probability of failure should be considered to have a correct analysis of the issue. In 2014, an attempt was made to evaluate structural robustness using a reliability-based framework in the presence of earthquakes (mainshock) and aftershocks. The results indicated that structural reliability under a single seismic event is different from a sequence of seismic events, and the structural robustness also depends on the amount of damage caused by each tremor [59].

As discussed, corrosion is a serious factor affecting the life reduction of offshore platforms due to chemical reactions and the decline of minimum breaking strength. Furthermore, wave climate change is another factor that is not usually fully addressed in research. Wave climate change can greatly affect the life of offshore structures due to its significant alternations during the year, and because it depends on different agents, such as tidal and moon impacts, temperature, typhoons, etc. [60]. Du et al. reported that if the simultaneous effects of marine corrosion and wave climate change on fatigue life are overlooked, it is possible that fatigue life evaluation faces up to a $35 \%$ error in the long term [61]. Therefore, the effects of these factors on reliability and the probability of failure should be considered to obtain results that are close to reality. Unfortunately, due to the high uncertainties, researchers have difficulty applying these factors to their calculations, because it is too conservative to consider simplified modes, such as the linear corrosion growth model (LCGM). Nevertheless, research into more complete examples continues, for example, the time-dependent corrosion wastage model of metal structure [62,63].

Since, at development stage of any object, a failure may occur, then the object resistance against a mechanical failure should be always considered and this is one of the main challenges which most researchers are facing. However, the process of recognizing and estimating the strength of objects has gone from experimental and elementary methods to completely scientific methods in the present century. Various criteria and methods, such as pushover analysis, global-local fatigue methodology [64], and multi-failure paths, have been proposed to evaluate the failure probability and lifetime of offshore platforms, which have been selected based on available data, as well as environmental and local conditions. However, it should be noted that the superiority of these methods relative to each other is vague, and more attention has been paid to the presentation of new models. In this regard, some common methods and their results are summarized in Table 3.

Table 3. Various methods of failure assessment used in marine structure.

\begin{tabular}{cccc}
\hline Author & Year & Method and Condition & Results \\
\hline $\begin{array}{c}\text { Kurian et al. } \\
\text { [65] }\end{array}$ & 2013 & $\begin{array}{c}\text { Pushover analysis } \\
\text { Bayesian updating theory for } \\
\text { updating the failure probability }\end{array}$ & Maximum environmental load \\
\hline $\begin{array}{c}\text { Ayob et al. } \\
\text { [66] }\end{array}$ & 2014 & $\begin{array}{c}\text { Global ultimate strength assessment } \\
\text { Simplified structural reliability } \\
\text { analysis }\end{array}$ & $\begin{array}{c}\text { Optimum mitigation measures } \\
\text { Different failure modes } \\
\text { Maximum environmental load }\end{array}$ \\
\hline $\begin{array}{c}\text { Li et al. } \\
\text { [67] }\end{array}$ & 2016 & The damage control methods & $\begin{array}{c}\text { The rib reinforcement can slow } \\
\text { down the structural damage }\end{array}$ \\
\hline
\end{tabular}


Table 3. Cont.

\begin{tabular}{|c|c|c|c|}
\hline Author & Year & Method and Condition & Results \\
\hline $\begin{array}{l}\text { Yu et al. } \\
{[68]}\end{array}$ & 2019 & $\begin{array}{l}\text { The ice-induced steady-state } \\
\text { vibration mechanism analysis }\end{array}$ & $\begin{array}{l}\text { The mechanism of failure } \\
\text { The failure criteria }\end{array}$ \\
\hline $\begin{array}{l}\text { Lin et al. } \\
\text { [69] }\end{array}$ & 2019 & $\begin{array}{c}\text { Path-dependent and } \\
\text { state-dependent robustness index } R_{I} \\
\text { Structural overall dynamic } \\
\text { robustness index } R_{P} \\
\text { Structural comprehensive } \\
\text { robustness index } R_{W} \\
\text { Bearing-capacity-ratio method } \\
\text { combined with the } \\
\text { incremental-loading method }\end{array}$ & $\begin{array}{c}\text { Structural robustness assessment } \\
\text { Determining all possible failure } \\
\text { paths } \\
\text { Robustness changes in different } \\
\text { failure paths are different so that } \\
\text { an unintended accident in small } \\
\text { probability paths has a severe } \\
\text { effect on structural robustness }\end{array}$ \\
\hline $\begin{array}{l}\text { Moradi et al. } \\
\text { [70] }\end{array}$ & 2020 & $\begin{array}{c}\text { Pushover analysis } \\
\text { The legs slope of jacket platforms }\end{array}$ & $\begin{array}{l}\text { The improvement of safety } \\
\text { factors and platform behavior }\end{array}$ \\
\hline
\end{tabular}

Failures that occur under dynamic loading conditions are generally called fatigue failures. The main reason that why a fatigue failure is dangerous, is that it occurs without prior awareness and visibility [71,72]. Fatigue failure in a brittle part occurs without any significant deformation. Since offshore platforms are faced with a variety of dynamic forces due to waves, wind, etc., fatigue analysis of these structures is inevitable to guarantee financial and human capital. Failure-based design is a method which has been used to design parts or structres in a platform. In most of these studies, finding the weakest part of the structure and be strengthening it has been attempted [73]. In examining the fatigue life of offshore platforms, methods such as deterministic, spectral methods [74], and S-N curve approach [75] have acceptable performance. Figure 14 demonstrates a typical flowchart for assessing the fatigue life of offshore platforms. Accordingly, the first step is data retrieval. It can be said that this stage is of significant importance, and the accuracy of the results is tied to the precision of the initial measured information. Therefore, the method selection and accuracy of sensors is very important in evaluating fatigue life [76].

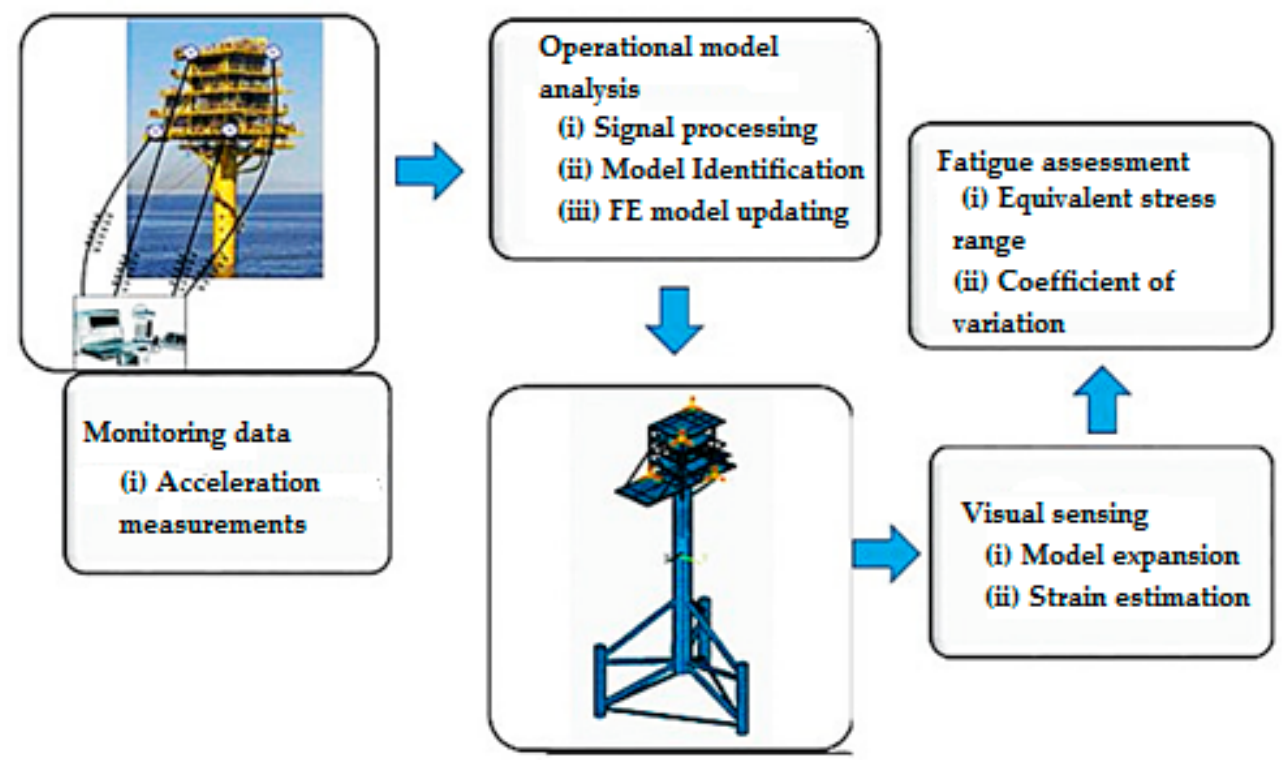

Figure 14. The methodology of fatigue analysis [76].

Figure 15 presents the comparison of optimization results of critical zones which is related to an SPD19A platform located in the South Pars field in the Persian Gulf. CF is one of the optimization methods that has specific constraints, including fatigue life 
in connections, horizontal displacement at the working point level, stress and buckling design requirements in structural members, and structural adequacy control of connections. Another optimization method is WCF, which has all constraints except fatigue life in connections. The members of the structure in terms of their positions were divided into several groups: H, LB, GL, and VB. The use of optimization methods based on the genetic algorithms is very helpful in solving complex problems with many parameters, and fortunately this method is constantly being updated $[77,78]$.

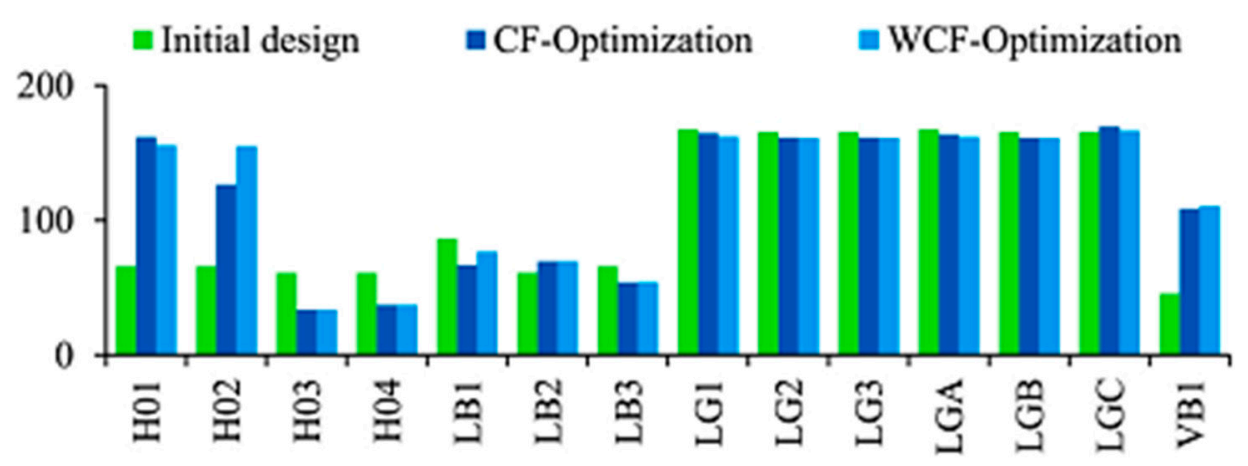

(a)

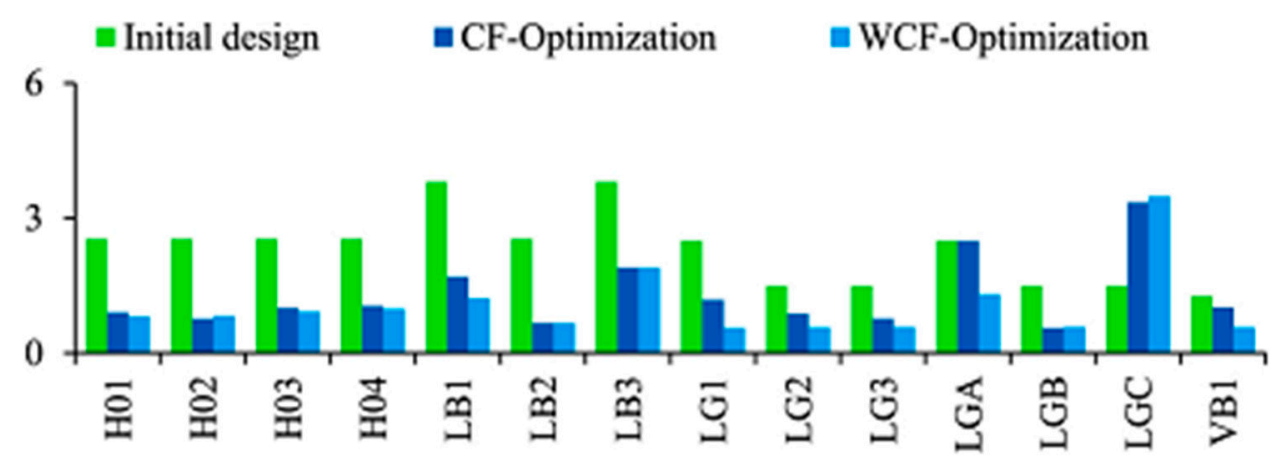

(b)

Figure 15. Comparison of various optimization methods with and without considering fatigue life criterion as the constraint [78]. (a) The outer diameter (cm), (b) The thickness (cm).

Joints, especially welds, are the most sensitive parts that are prone to failure [79-81]. In other words, stress concentration, which is a destructive factor in fatigue life, causes the connection, especially tubular joints (TJ), to fail. Fortunately, the importance of this issue and the progression of numerical methods have led to the introduction of new models and methods of welding and joining to reduce the impact of the stress concentration and increase the safety factor [82].

In the end, it is worthwhile to be note that by studying previous works, it can be inferred that, despite remarkable characteristics in the prediction and monitoring of systems and structures and applications in the various fields, the vacancy of neural networks and artificial intelligence in the discussion of design and control of offshore platforms remains [83].

\section{Conclusions}

In the present study, the authors have attempted to provide a comprehensive review on the latest and practical methods and approaches affecting the design, construction, control, reliability, and the most important factors influencing on failure and fatigue life of offshore platforms. The most important points of this research are:

- Research shows that Europe has made a targeted and strong investment in generating electricity through wind turbines installed in offshore structures. In the next few years, 
it will increase its dependence on this industry five times what it is now. This requires extensive research on this subject, and scholars will pay more attention to it.

- One of the most evident environmental problems of wind turbines is dealing with migratory birds. Therefore, the issue of bird migration and their routes should be considered in the design of wind turbine installation by engineers. In this regard, the problems of offshore wind turbines are far less than those of wind turbines on land.

- One of the most essential design criteria in offshore structures, especially wind turbines, is to consider the dynamic behavior of the structure under wind loads and forces from sea wave clashes. It is also very important to study the corrosion phenomenon due to the salinity of seawater. In addition, the study of the simultaneous impact of this phenomenon and the previously mentioned dynamic forces is very complex, which makes it necessary to accurately estimate the service life of equipment. In addition, the possible occurrence of some events should be considered according to the geographical situations like storms, earthquakes, and freeze.

- One of the most common events that cause damage and shortens the life of naval platforms is the possibility of ships and other floating objects colliding with the platforms, because ships are constantly moving, docking to carry oil/gas and staff, etc.

- The most sensitive parts of marine structures, which are prone to failure under cyclic fatigue loads are different types of welds and joints.

- There are different methods to improve the strength of offshore platforms, including, eliminating irregularities, adding additional parts, use of energy dissipation systems, etc., but in all of them, special attention should be paid to the problems caused by asymmetry in the system.

- Assessing and monitoring the health of offshore structures is crucial due to financial and human interests, so an expert team should be involved in this area. On the other hand, this issue is more important than the design stage. The design process is done in one step and, after the construction, the work of that team is completed, but the inspection team in each period addresses changes in working conditions and equipment health and must make new decisions. In other words, the task of the inspection team is dynamic. Therefore, different methods for evaluating these structures are presented and developed by researchers.

- This comprehensive review helps and guides scholars, engineers, and designers of offshore platforms to find suitable ideas and appropriate methods to advance their projects.

- Additionally, according to the literature review, there are several valuable suggestions for future work, including:

- The lack of using artificial intelligence methods in this scope is noticeable and should be considered, because these methods have remarkable potentials in predicting affected factors and solving problems to enhance the quality of evaluations.

- By employing deep learning machine tools, the life and damage in large structures can be predicted and heavy repair costs and long downtime for replacement of damaged parts can be avoided.

Author Contributions: All authors contributed to the study's conception and design. Conceptualization, investigation, and resources by M.S.; writing — original draft, data collection and validation by N.A.; project supervision, and assistant in writing-review and editing by K.R.K. and M.C. were performed. All authors have read and agreed to the published version of the manuscript.

Funding: This research received no external funding.

Informed Consent Statement: Informed consent was obtained from all subjects involved in the study.

Data Availability Statement: The data that support the findings of this study are available from the corresponding author upon reasonable request. 
Acknowledgments: This paper has been supported by the RUDN University Strategic Academic Leadership Program.

Conflicts of Interest: The authors declare no conflict of interest.

\section{References}

1. McClelland, B.; Reifel, M.D. Planning and Design of Fixed Offshore Platforms; U.S. Department of Energy: Washington, DC, USA, 1986.

2. Omidi Bidgoli, M.; Kashyzadeh, K.R.; Rahimian Koloor, S.S.; Petrů, M.; Amiri, N. Optimum Design of Sunken Reinforced Enclosures under Buckling Condition. Appl. Sci. 2020, 10, 8449. [CrossRef]

3. Bea, R.; Xu, T.; Stear, J.; Ramos, R. Wave forces on decks of offshore platforms. J. Waterw. Port Coast. Ocean Eng. 1999, 125, 136-144. [CrossRef]

4. Available online: https://windeurope.org/policy/topics/offshore-wind-ports/ (accessed on 6 September 2021).

5. Bailey, H.; Brookes, K.L.; Thompson, P.M. Assessing environmental impacts of offshore wind farms: Lessons learned and recommendations for the future. Aquat. Biosyst. 2014, 10, 1-13. [CrossRef]

6. Price, S.J.; Figueira, R.B. Corrosion protection systems and fatigue corrosion in offshore wind structures: Current status and future perspectives. Coatings 2017, 7, 25. [CrossRef]

7. Bea, R.G. Earthquake and wave design criteria for offshore platforms. J. Struct. Div. 1979, 105, 401-419. [CrossRef]

8. Ryerson, C.C. Assessment of Superstructure Ice Protection as Applied to Offshore Oil Operations Safety: Problems, Hazards, Needs, and Potential Transfer Technologies; US Army Corps of Engineers: Wallisville, TX, USA, 2008.

9. Beer, M.; Liebscher, M. Designing robust structures-a nonlinear simulation based approach. Comput. Struct. 2008, 86, 1102-1122. [CrossRef]

10. Formisano, A.; Landolfo, R.; Mazzolani, F. Robustness assessment approaches for steel framed structures under catastrophic events. Comput. Struct. 2015, 147, 216-228. [CrossRef]

11. Sarrafan, A.; Zareh, S.H.; Khayyat, A.A.A.; Zabihollah, A. Neuro-fuzzy control strategy for an offshore steel jacket platform subjected to wave-induced forces using magnetorheological dampers. J. Mech. Sci. Technol. 2012, 26, 1179-1196. [CrossRef]

12. Shaterabadi, M.; Jirdehi, M.A.; Amiri, N.; Omidi, S. Enhancement the economical and environmental aspects of plus-zero energy buildings integrated with INVELOX turbines. Renew. Energy 2020, 153, 1355-1367. [CrossRef]

13. Singh, H.; Gupta, M.M.; Meitzler, T.; Hou, Z.G.; Garg, K.K.; Solo, A.M.; Zadeh, L.A. Real-life applications of fuzzy logic. Adv. Fuzzy Syst. 2013, 2013, 581879. [CrossRef]

14. Zhang, Y. Comparing the robustness of offshore structures with marine deteriorations-a fuzzy approach. Adv. Struct. Eng. 2015, 18, 1159-1171. [CrossRef]

15. Wang, Z.; Zhang, B.; Wang, T. Mechanical test and buckling analysis of X-type grouted clamps for the offshore platform structures. IOP Conf. Ser. Mater. Sci. Eng. 2019, 474, 012015. [CrossRef]

16. Wang, Z.; Wang, Q.C.; Wang, T. Mechanics Experiments and Analysis of Grouting Clamp Reinforcement to Local Defects on the Ocean Jacket. J. Phys. Conf. Ser. 2018, 1087, 042050. [CrossRef]

17. Moharrami, M.; Tootkaboni, M. Reducing response of offshore platforms to wave loads using hydrodynamic buoyant mass dampers. Eng. Struct. 2014, 81, 162-174. [CrossRef]

18. Jafarabad, A.; Kashani, M.; Parvar, M.R.A.; Golafshani, A.A. Hybrid damping systems in offshore jacket platforms with float-over deck. J. Constr. Steel Res. 2014, 98, 178-187. [CrossRef]

19. Zhang, B.L.; Liu, Y.J.; Han, Q.L.; Tang, G.Y. Optimal tracking control with feedforward compensation for offshore steel jacket platforms with active mass damper mechanisms. J. Vib. Control 2016, 22, 695-709. [CrossRef]

20. Zhang, B.L.; Liu, Y.J.; Ma, H.; Tang, G.Y. Discrete feedforward and feedback optimal tracking control for offshore steel jacket platforms. Ocean Eng. 2014, 91, 371-378. [CrossRef]

21. Asgarian, B.; Aghakouchak, A.; Alanjari, P.; Assareh, M. Incremental dynamic analysis of jacket type offshore platforms considering soil-pile interaction. In Proceedings of the 14th World Conference on Earthquake Engineering, Beijing, China, 12-17 October 2008; pp. 12-17.

22. Bea, R. Criteria for design and requalification of platforms in the bay of Campeche, Mexico. J. Waterw. Port Coast. Ocean Eng. 2000, 126, 254-262. [CrossRef]

23. Zhang, D.; Yue, Q. Major challenges of offshore platforms design for shallow water oil and gas field in moderate ice conditions. Ocean Eng. 2011, 38, 1220-1224. [CrossRef]

24. Wang, S.; Yue, Q.; Zhang, D. Ice-induced non-structure vibration reduction of jacket platforms with isolation cone system. Ocean Eng. 2013, 70, 118-123. [CrossRef]

25. Wang, S.Q.; Li, N. Semi-active vibration control for offshore platforms based on LQG method. J. Mar. Sci. Technol. 2021, $21,9$.

26. Wu, B.; Shi, P.; Wang, Q.; Guan, X.; Ou, J. Performance of an offshore platform with MR dampers subjected to ice and earthquake. Struct. Control Health Monit. 2011, 18, 682-697. [CrossRef]

27. Mostafa, Y.E.; El Naggar, M.H. Response of fixed offshore platforms to wave and current loading including soil-structure interaction. Soil Dyn. Earthq. Eng. 2004, 24, 357-368. [CrossRef]

28. Azman, N.U.; Husain, M.K.A.; Zaki, N.I.M.; Soom, E.M.; Mukhlas, N.A.; Ahmad, S.Z.A.S. Structural Integrity of Fixed Offshore Platforms by Incorporating Wave-in-Deck. J. Mar. Sci. Eng. 2021, 9, 1027. [CrossRef] 
29. Hosseini, S.; Zolghadr, A. Optimization of an offshore jacket-type structure using meta-heuristic algorithms. Iran Univ. Sci. Technol. 2017, 7, 565-577.

30. Zhang, X.; Song, X.; Qiu, W.; Yuan, Z.; You, Y.; Deng, N. Multi-objective optimization of Tension Leg Platform using evolutionary algorithm based on surrogate model. Ocean Eng. 2018, 148, 612-631. [CrossRef]

31. Abou El-Makarem, M.; Elshafey, A.A.; Abdel-Salam, A.; Mokhtar, B.I.T. Topology Optimization of Fixed Offshore Platform under Earthquake Loading in Gulf of Suez. IOSR J. Mech. Civ. Eng. 2019, 16, 58-71.

32. Tian, X.; Wang, Q.; Liu, G.; Liu, Y.; Xie, Y.; Deng, W. Topology optimization design for offshore platform jacket structure. Appl. Ocean Res. 2019, 84, 38-50. [CrossRef]

33. Deng, W.; Tian, X.; Han, X.; Liu, G.; Xie, Y.; Li, Z. Topology optimization of jack-up offshore platform leg structure. Proc. Inst. Mech. Eng. Part M J. Eng. Marit. Environ. 2021, 235, 165-175. [CrossRef]

34. Babaei, S.; Amirabadi, R.; Sharifi, M.; Ventura, C. Optimal probabilistic seismic demand model for fixed pile-founded offshore platforms considering soil-pile-structure interaction. Structures 2021, 33, 4330-4343. [CrossRef]

35. Ajamy, A.; Asgarian, B.; Ventura, C.; Zolfaghari, M. Seismic fragility analysis of jacket type offshore platforms considering soil-pile-structure interaction. Eng. Struct. 2018, 174, 198-211. [CrossRef]

36. Mazaheri, P.; Asgarian, B.; Gholami, H. Assessment of strengthening, modification, and repair techniques for aging fixed offshore steel platforms. Appl. Ocean Res. 2021, 110, 102612. [CrossRef]

37. Samarakoon, S.M.; Ratnayake, R.C. Strengthening, modification and repair techniques' prioritization for structural integrity control of ageing offshore structures. Reliab. Eng. Syst. Saf. 2015, 135, 15-26. [CrossRef]

38. Skafte, A.; Tygesen, U.T.; Brincker, R. Expansion of mode shapes and responses on the offshore platform Valdemar. Dyn. Civ. Struct. 2014, 4, 35-41.

39. Ghadimi, B.; Taghikhany, T. Dynamic response assessment of an offshore jacket platform with semi-active fuzzy-based controller: A case study. Ocean Eng. 2021, 238, 109747. [CrossRef]

40. Jiang, X.; Han, Q.L. On Ho control for linear systems with interval time-varying delay. Automatica 2005, 41, 2099-2106. [CrossRef]

41. Zhang, B.L.; Huang, Z.W.; Han, Q.L. Delayed non-fragile $\mathrm{H} \infty$ control for offshore steel jacket platforms. In Proceedings of the IECON 2012-38th Annual Conference on IEEE Industrial Electronics Society, Montreal, QC, Canada, 15-28 October 2012; pp. 2216-2221.

42. Zhang, B.L.; Tang, G.Y. Active vibration Ho control of offshore steel jacket platforms using delayed feedback. J. Sound Vib. 2013, 332, 5662-5677. [CrossRef]

43. Zhang, B.L.; Han, Q.L. Robust sliding mode Ho control using time-varying delayed states for offshore steel jacket platforms. In Proceedings of the 2013 IEEE International Symposium on Industrial Electronics, Taipei, Taiwan, 28-31 May 2013 ; pp. 1-6.

44. Yang, J.S. Robust mixedH $\mathrm{H}_{2} / \mathrm{H} \infty$ active control for offshore steel jacket platform. Nonlinear Dyn. 2014, 78, 1503-1514. [CrossRef]

45. Sakthivel, R.; Selvaraj, P.; Mathiyalagan, K.; Park, J.H. Robust fault-tolerant $\mathrm{H} \infty$ control for offshore steel jacket platforms via sampled-data approach. J. Frankl. Inst. 2015, 352, 2259-2279. [CrossRef]

46. Zhang, B.L.; Han, Q.L.; Zhang, X.M. Event-triggered Ho reliable control for offshore structures in network environments. J. Sound Vib. 2016, 368, 1-21. [CrossRef]

47. Zhang, B.L.; Feng, A.M.; Li, J. Observer-based optimal fault-tolerant control for offshore platforms. Comput. Electr. Eng. 2014, 40, 2204-2215. [CrossRef]

48. Mujeeb-Ahmed, M.; Seo, J.K.; Paik, J.K. Probabilistic approach for collision risk analysis of powered vessel with offshore platforms. Ocean Eng. 2018, 151, 206-221. [CrossRef]

49. Mujeeb-Ahmed, M.; Ince, S.T.; Paik, J.K. Computational models for the structural crashworthiness analysis of a fixed-type offshore platform in collisions with an offshore supply vessel. Thin-Walled Struct. 2020, 154, 106868. [CrossRef]

50. Yu, Z.; Amdahl, J. Analysis and design of offshore tubular members against ship impacts. Mar. Struct. 2018, 58, 109-135. [CrossRef]

51. Ahn, J.H.; Choi, W.R.; Jeon, S.H.; Kim, S.H.; Kim, I.T. Residual compressive strength of inclined steel tubular members with local corrosion. Appl. Ocean Res. 2016, 59, 498-509. [CrossRef]

52. Aliev, T.; Alizada, T.; Rzayeva, N. Noise technologies and systems for monitoring the beginning of the latent period of accidents on fixed platforms. Mech. Syst. Signal Process. 2017, 87, 111-123. [CrossRef]

53. Ghasemi, M.R.; Shabakhty, N.; Enferadi, M.H. Optimized SMA dampers in vibration control of jacket-type offshore structures (regular waves). Int. J. Coast. Offshore Eng. 2019, 2, 25-35. [CrossRef]

54. Shabakhty, N.; Givkay, A.; Golara, A.; Heidari, P.S.N. Response of fixed offshore oil and gas platforms equipped with shape memory alloy elements under extreme wave loading. In Proceedings of the16th European Conference on Earthquake Engineering (16ECEE), Thessaloniki, Greece, 18-21 June 2018.

55. Zareie, S.; Zabihollah, A. A semi-active SMA-MRF structural stability element for seismic control in marine structures. Appl. Ocean Res. 2020, 100, 102161. [CrossRef]

56. Enferadi, M.H.; Ghasemi, M.R.; Shabakhty, N. Wave-induced vibration control of offshore jacket platforms through SMA dampers. Appl. Ocean Res. 2019, 90, 101848. [CrossRef]

57. Kurian, V.J.; Abdul Wahab, M.M.; Kheang, T.S.; Liew, M.S. System reliability of existing jacket platform in Malaysian water (failure path and system reliability index). Appl. Mech. Mater. 2014, 567, 307-312. [CrossRef] 
58. Gholizad, A.; Golafshani, A.; Akrami, V. Structural reliability of offshore platforms considering fatigue damage and different failure scenarios. Ocean Eng. 2012, 46, 1-8. [CrossRef]

59. Ribeiro, F.L.; Barbosa, A.R.; Neves, L.C. Application of reliability-based robustness assessment of steel moment resisting frame structures under post-mainshock cascading events. J. Struct. Eng. 2014, 140, A4014008. [CrossRef]

60. Jimenez Martinez, M. Harbor and coastal structures: A review of mechanical fatigue under random wave loading. Heliyon 2021, 7, e08241. [CrossRef]

61. Du, J.; Wang, H.; Wang, S.; Song, X.; Wang, J.; Chang, A. Fatigue damage assessment of mooring lines under the effect of wave climate change and marine corrosion. Ocean. Eng. 2020, 206, 107303. [CrossRef]

62. Kim, D.K.; Lim, H.L.; Cho, N.K. An advanced technique to predict time-dependent corrosion damage of onshore, offshore, nearshore and ship structures: Part II-Application to the ship's ballast tank. Int. J. Nav. Archit. Ocean Eng. 2020, 12, 645-656. [CrossRef]

63. Zhang, M.; Beer, M.; Quek, S.; Choo, Y. Comparison of uncertainty models in reliability analysis of offshore structures under marine corrosion. Struct. Saf. 2010, 32, 425-432. [CrossRef]

64. Mourão, A.; Correia, J.A.; Avila, B.V.; de Oliveria, C.C.; Ferradosa, T.; Carvalho, H.; Castro, J.M.; De Jesus, A.M.P. A fatigue damage evaluation using local damage parameters for an offshore structure. Proc. Inst. Civ. Eng. Marit. Eng. 2020, $173,43-57$. [CrossRef]

65. Kurian, V.; Nizamani, Z.; Liew, M. Bayesian updating for probability of failure of jacket platforms in Malaysia. In Proceedings of the IEEE Business Engineering and Industrial Applications Colloquium (BEIAC), Langkawi, Malaysia, 7-9 April 2013; pp. 267-272.

66. Ayob, M.; Kajuputra, A.; Mukherjee, K.; Wong, B. Global ultimate strength assessment of existing offshore jacket structures. In Proceedings of the Offshore Technology Conference-Asia, Kuala Lumpur, Malaysia, 25-28 March 2014.

67. Li, P.; Lin, H.; Yang, L.; Zhang, Y.; Qi, B. Failure mode analysis and damage control for jacket platform structures. In Proceedings of the 5th International Conference on Civil, Architectural and Hydraulic Engineering (ICCAHE 2016), Zhuhai, China, 30-31 July 2016.

68. Yu, S.; Zhang, D.; Yue, Q. Failure analysis of topside facilities on oil/gas platforms in the Bohai Sea. J. Mar. Sci. Eng. 2019, 7, 86. [CrossRef]

69. Lin, H.; Yang, L.; Chen, G.; Li, P.; Qi, B. A novel methodology for structural robustness assessment of offshore platforms in progressive collapse. J. Loss Prev. Process Ind. 2019, 62, 103966. [CrossRef]

70. Moradi, H.; Karimi, H.R.; KaramZadeh, N.S.; Golami, E.O.D.R. Effects of leg slope on the failure of fixed jacket platforms: A case study of south pars gas Field's platforms. Ocean Eng. 2020, 210, 107401. [CrossRef]

71. Arghavan, A.; Reza Kashyzadeh, K.; Asfarjani, A.A. Investigating effect of industrial coatings on fatigue damage. Appl. Mech. Mater. 2011, 87, 230-237. [CrossRef]

72. Kashyzadeh, K.R.; Arghavan, A. Study of the effect of different industrial coating with microscale thickness on the CK45 steel by experimental and finite element methods. Strength Mater. 2013, 45, 748-757. [CrossRef]

73. Khalifa, A.; Haggag, S.; Fayed, M. Fatigue assessment analysis of offshore structures with application to an existing platform in Suez Gulf, Egypt. World Appl. Sci. J. 2014, 30, 1000-1019.

74. Havigh, S.N.; Askar, M.B. The process of fatigue analysis on fixed metal offshore platforms. Mar. Sci. 2017, 7, 10-16.

75. Saadian, R.; Taheri, A. Fatigue damage analysis of an existing fixed offshore platform using spectral method for life extension. $J$. Mar. Sci. Technol. 2018, 23, 877-887. [CrossRef]

76. Nabuco, B.; Tarpø, M.; Tygesen, U.T.; Brincker, R. Fatigue stress estimation of an offshore jacket structure based on operational modal analysis. Shock Vib. 2020, 2020, 7890247. [CrossRef]

77. Amiri, N.; Farrahi, G.H.; Kashyzadeh, K.R.; Chizari, M. Applications of ultrasonic testing and machine learning methods to predict the static \& fatigue behavior of spot-welded joints. J. Manuf. Process. 2020, 52, 26-34.

78. Motlagh, A.A.; Shabakhty, N.; Kaveh, A. Design optimization of jacket offshore platform considering fatigue damage using Genetic Algorithm. Ocean Eng. 2021, 227, 108869. [CrossRef]

79. Farrahi, G.H.; Chamani, M.; Kashyzadeh, K.R.; Mostafazadeh, A.; Mahmudi, A.H.; Afshin, H. Failure analysis of bolt connections in fired heater of a petrochemical unit. Eng. Fail. Anal. 2018, 92, 327-342. [CrossRef]

80. Ahmadi, A.; Farrahi, G.H.; Reza Kashyzadeh, K.; Azadi, S.; Jahani, K. A comparative study on the fatigue life of the vehicle body spot welds using different numerical techniques: Inertia relief and Modal dynamic analyses. Frat. Integrità Strutt. 2020, 14, 67-81.

81. Farrahi, G.H.; Ahmadi, A.; Reza Kashyzadeh, K. Simulation of vehicle body spot weld failures due to fatigue by considering road roughness and vehicle velocity. Simul. Model. Pract. Theory 2020, 105, 102168. [CrossRef]

82. Hammerstad, B.H.; Schafhirt, S.; Muskulus, M. On fatigue damage assessment for offshore support structures with tubular joints. Energy Procedia 2016, 94, 339-346. [CrossRef]

83. Ghafarallahi, E.; Farrahi, G.H.; Amiri, N. Acoustic simulation of ultrasonic testing and neural network used for diameter prediction of three-sheet spot welded joints. J. Manuf. Process. 2021, 64, 1507-1516. [CrossRef] 